\title{
Hubungan Persepsi Siswa-Siswi Sekolah Dasar Terhadap Perilaku Kekerasan Oleh Orang Tua Di Kota Jambi
}

\section{The Relationship between Elementary School Students' Perceptions of Violent Behavior by Parents in Jambi City}

\author{
Iis Hartini*, Suandi \& Fuad Muchlis \\ Jurusan Kependudukan, Fakultas Ilmu Kependudukan dan Ketenagakerjaan, \\ Universitas Jambi, Indonesia \\ Diterima: 30 Agustus 2020; Direview: 13 Oktober 2020; Disetujui:03 November 2020 \\ *Coresponding Email: hi iis@vahoo.com
}

\begin{abstract}
Abstrak
Di Provinsi Jambi, perilaku kekerasan terhadap anak tergolong cukup tinggi yaitu mencapai 72 anak setiap tahun. Studi dilakukan di SDN 47, SDN 69, dan SDN 208 Kota Jambi dengan populasi siswa siswi kelas 6 dengan sampel 90 orang. Variabel yang diteliti adalah jenis kekerasan yang di alami oleh anak, persepsi anak terhadap kekerasan dan faktor sosial ekonomi yang mempengaruhi terjadinya kekerasan pada anak. Aspek kekerasan pada anak yang diteliti adalah kekerasan fisik, kekerasan psikis, dan kekerasan seksual. Penelitian ini dilakukan dengan metode deskriptik analitik, di analisis secara kuantitatif yang dilakukan dengan analisis statistik deskriptif dan statistik inferensial yang menggunakan korelasi chi square dengan jenis data kategorikal. Dari hasil penelitian ini, didapatkan bahwa kekerasan psikis (22\%) yang paling banyak dialami oleh siswa-siswi tersebut. Untuk aspek persepsi anak terhadap kekerasan dapat disimpulkan siswa-siswi tersebut memahami tentang kekerasan pada anak dan tidak setuju terhadap kekerasan pada anak. Sedangkan variabel sosial ekonomi yang memiliki hubungan signifikan dengan perilaku kekerasan, yaitu pendidikan ibu dan usia ibu dimana nilai probabilitas menunjukkan nilai yang kurang dari 0,05 yaitu 0,027 dan 0,041. Dengan demikian artinya bahwa pendidikan ibu dan usia ibu memiliki keterkaitan dengan perilaku kekerasan pada anak.
\end{abstract}

Kata kunci: Anak, Kekerasan, Siswa-Siswi, Persepsi, Sosial Ekonomi

\begin{abstract}
In Jambi Province, the behavior of violence against children was quite high, reaching 72 children each year. This study is conducted at SDN 47, SDN 69, and SDN 208 Jambi City with a population of $6^{\text {th }}$ grade students with a sample of 90 people. The variables studied consists the types of violence experienced by children, children's perceptions of violence and socio-economic factors that influence the occurrence of violence against children. The aspects of violence against children studied were physical violence, psychological violence, and sexual violence. The aspects of perception are consists of cognition, affection and conation. This research was conducted using descriptive analytical method, in quantitative analysis carried out by descriptive statistical analysis and inferential statistics using chi square correlation with categorical data types. The results of this study concluded that psychological violence (22\%) was mostly experienced by these students. Aspect of children's perceptions of violence can be concluded that these students understand about violence against children and do not agree with violence against children. The socio-economic variables that have a significant relationship with violent behavior are maternal education $(0,027)$ and maternal age $(0,041)$ where the probability value shows a value less than 0.05. It means that maternal education and maternal age are related to violent behavior in children.
\end{abstract}

Key Word: Children, Violence, Students, Perception, Socio-Economic

How to Cite: Hartini, I., Suandi \& Muchlis, F., (2020). Hubungan Persepsi Siswa - Siswi Sekolah Dasar Terhadap Perilaku Kekerasan Oleh Orang Tua di Kota Jambi. Journal of Education, Humaniora and Social Sciences (JEHSS). 3(2): 394-400. 


\section{PENDAHULUAN}

Anak sebagai bagian dari generasi muda adalah merupakan penerus cita-cita perjuangan bangsa dan juga merupakan sumber daya manusia (SDM) yang sangat potensial bagi pembangunan nasional. Oleh karena itu, dalam rangka tersedianya sumber daya manusia yang berkualitas dan mampu memimpin serta memelihara kesatuan dan persatuan bangsa dalam wadah Negara Kesatuan Republik Indonesia (NKRI) berdasarkan Pancasila dan Undang-Undang Dasar 1945.

Kekerasan terhadap anak senantiasa berulang terus terjadi sepanjang kehidupan manusia. Dari tahun ketahun angka kekerasan terhadap anak semakin lama semakin meningkat. Data dari Komisi Perlindungan Anak Indonesia (KPAI) menyebutkan terjadi peningkatan kekerasan terhadap anak.Baik secara seksual, fisik maupun eksploitasi seksual komersil, Dari jumlah itu kekerasan fisik tercatat ada 294 kasus atau 28 persen, kekerasan psikis 203 kasus atau 20 persen dan kekerasan seksual 535 kasus atau 52 persen (KPAI, 2018).

\begin{tabular}{lll}
\multicolumn{2}{c}{ Tabel 1.1 Jumlah Kasus Kekerasan Pada Anak 5 Tahun Terakhir } \\
\hline Tahun & Indonesia & Jambi \\
\hline 2015 & 4309 & 28 \\
2016 & 4622 & 65 \\
2017 & 4579 & 52 \\
2018 & 4885 & 72 \\
2019 & 4086 & 72 \\
\hline
\end{tabular}

Sumber: KPAI (Komisi Perlindungan Anak Indonesia)

Dari data jumlah kekerasan di Kota Jambi tahun 2019 ada sekitar 30 kasus dan kabupaten di provinsi Jambi jumlah kasus paling rendah terhadap kekerasan yaitu kabupaten Muaro Bungo (KPAI, 2019). Kekerasan anak di provinsi Jambi saat ini tergolong tinggi, faktor pemicu terjadinya kekerasan terhadap anak, rata - rata adalah kurangnya ketahanan keluarga. Penyebab nya adalah dorongan ekonomi keluarga yang tidak mencukupi berbagai permasalahan yang tengah dihadapi, memicu orang tua dan orang yang tengah mengasuh anak menjadi stress, akibatnya orang tua dan pengasuh anak biasanya melampiaskan emosinya pada anak yang bahkan tidak mengerti apa-apa.

Beberapa solusi yang dilakukan untuk menanggulangi tingkat kekerasan pada anak adalah dengan menstimulus persepsi anak terhadap bentuk perlakukan kekerasan yang kerap terjadi di rumah. Leavitt (dalam Sobur 2003: 445) mendefinisikan persepsi dalam arti sempit ialah penglihatan, bagaimana cara seseorang melihat sesuatu, sedangkan dalam arti luas ialah pandangan atau pengertian, yaitu bagaimana seseorang memandang atau mengartikan sesuatu. Dalam pembentukan persepsi ditentukan oleh tiga faktor yaitu perceiver (orang yang memberikan persepsi), the object (orang yang menjadi sasaran persepsi), the situation yaitu keadaan pada saat persepsi dilakukan (Wibowo, 2014: 66). Kekerasan membawa dampak yang besar bagi perkembangan anak, baik itu psikologis, fisik juga mental anak. Jika anak dididik dengan kekerasan bisa dimungkinkan kelak ia akan mendidik anaknya dengan kekerasan pula. Banyak kasus yang menunjukkan bahwa tidak mungkin meremehkan pentingnya orang tua dalam memberikan contoh, seperti jenis pola pikir dan perilaku yang baik untuk dilihat maupun ditiru oleh anakanaknya (Firdinan, 2008)

Selanjutnya dalam pengetahuan mengenai kekerasan anak juga harus dibekali dengan devenisi dan bentuk dari beberapa tindakan kekerasan. Menurut Gelles (2004), pewarisan kekerasan antar generasi adalah perilaku kekerasan dipelajari seorang anak dari orangtuanya kemudian mengembangkannya ketika dewasa/ menjadi orangtua nantinya. Adapun beberapa bentuk kekerasan antara lain adalah kekerasan fisik, kekerasan emosional dan kekerasan seksual (Huraerah, 2007) . Menurut Tampubolon (2008) kekerasan fisik adalah semua tindakan yang mengakibatkan luka fisik pada anak. Kekerasan fisik itu meliputi menampar, menjewer, mencubit, memukul dengan dahan pohon, dengan tongkat, cambuk atau benda keras lainnya, melempar dengan benda keras, mendorong, menendang, membenturkan anak ke dinding, mengikat anak di pohon, push up, jalan dengan lutut dan dijemur. Selanjutnya Menurut Banton (2004) adapun 
contoh dari kekerasan emosional seperti memarahi, menghardik, memaki, mengatai anak sebagai anak yang tidak berguna, tidak dicintai, bodoh dan selalu mengecewakan orangtua; dan Vaughan (1996) menambahkannya yaitu membicarakan kegagalan anak terus menerus dan menghinanya. Bentuk yang terakhir adalah kekerasan seksual, menurut Suteja \& Ulum (2019) kekerasan seksual meliputi kontak fisik, penetrasi/ tidak penetrasi, memegang bagian tubuh yang tidak boleh disentuh, serta aktivitas bukan kontak fisik seperti mengajak anak menonton adegan porno, memperlihatkan gambar-gambar porno, menganjurkan anak untuk berperilaku yang tidak pantas seperti exhibitionism, mengajak anak berbicara porno, tindakan yang menyebabkan anak masuk dalam tujuan prostitusi atau menggunakan anak sebagai model foto porno.

Pada penelitian Novia Pratiwi dan Ery Khusnal (2014) dengan judul “Perbandingan Persepsi Tentang Kekerasan Anak Berdasarkan Karakteristik Demografi Orang Tua Di Dusun Mantaran Trimulyo Sleman Yogyakarta" mahasiswa STIKES Aisiyah berdasarkan penelitian ini karakteristik demografis orangtua meliputi umur, jenis kelamin, pendidikan dan pekerjaan. Persepsi orang tua yang salah mengakibatkan kekerasan anak terjadi dalam keluarga. Metode penelitian yang digunakan dalam penelitian ini adalah rancangan non eksperimental dengan pendekatan waktu cross sectional.

Penelitian yang dilakukan peneliti sekarang melengkapi penelitian terdahulu dan menambah penguatan terhadap beberapa teori yang telah dipaparkan dalam penelitian terdahulu. Penelitian sekarang ingin menenumakan dampak kekerasan yang dialami anak terhadap kecerdasan emosional yang dimiliki anak. Karena menurut peneliti untuk penelitian terdahulu masih membahas pada satu fokus kekerasan.

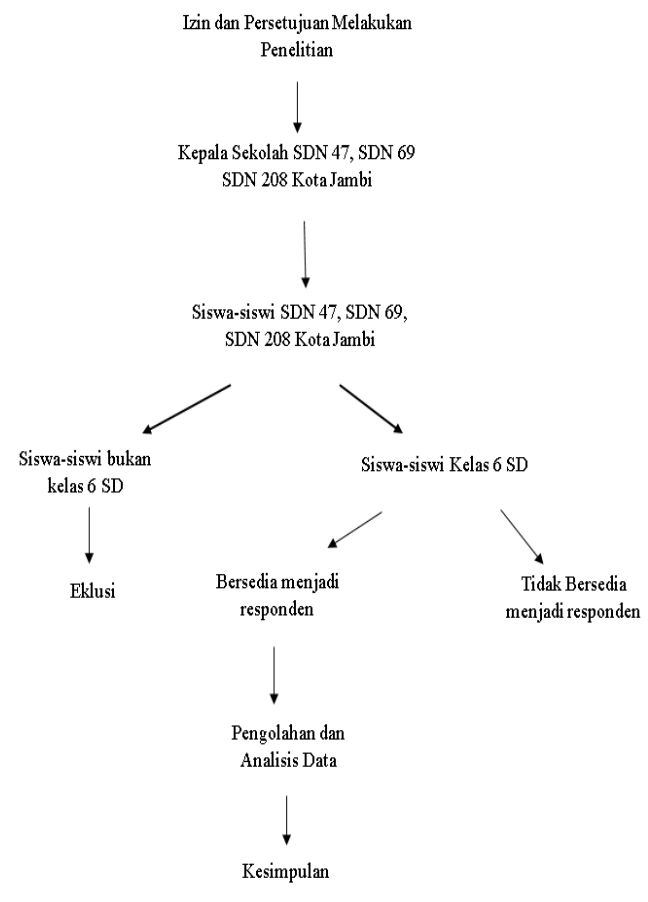

Gambar 1. Kerangka Penelitian

Kemampuan berfikir, perasaan dan pengalaman - pengalaman yang dimiliki setiap individu tidaklah sama maka respon setiap individu pasti berbeda. Setiap orang mempunyai kecenderungan melihat benda yang sama dengan cara yang berbeda. Hal tersebut dipengaruhi oleh beberapa faktor, seperti pengalaman, pengetahuan dan sudut pandangnya. Adapun faktor faktor yang mempengaruhi persepsi yaitu; Objek yang dipersiapkan, alat indera, faktor fungsional yaitu masa lalu, dan faktor struktural. 


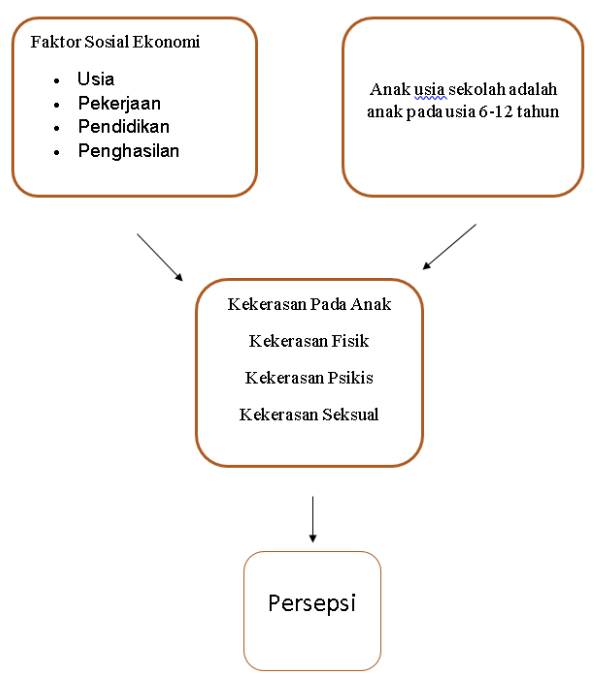

Gambar 2. Kerangka Teori Persepsi Anak Terhadap Perilaku Kekerasan

\section{METODE PENELITIAN}

Penelitian ini dilakukan di Sekolah Dasar Negeri 47 Kota Jambi, Sekolah Dasar Negeri 69 Kota Jambi, dan Sekolah Dasar Negeri 208 Kota Jambi. Objek yang akan diteliti merupakan siswa dan siswi di kelas 6. Waktu penelitian akan dilakukan pada bulan Juni - Juli 2020:

Penelitian ini salah satu bentuk penelitian kuantitatif yang dapat digunakan untuk mengetahui pendapat, keyakinan, atau karakteristik suatu populasi.Alat yang digunakan untuk mengumpulkan data berupa angket yang terdiri dari pertanyaan tertutup dan terbuka mengenai bentuk, dampak dan penyebab tindak kekerasan pada anak.

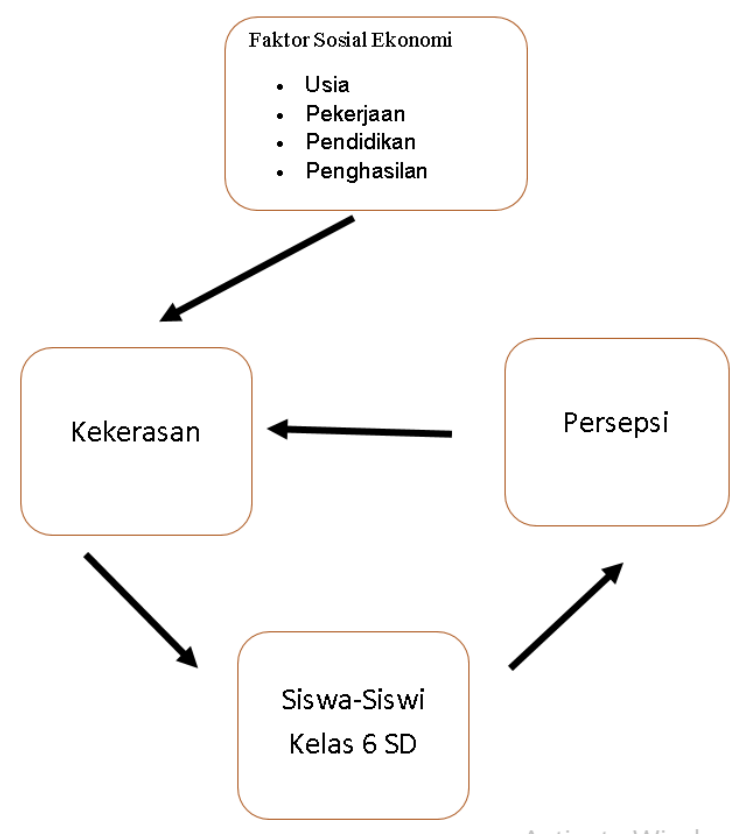

Gambar 3. Kerangka Konsep Persepsi Pada Anak Terhadap Perilaku Kekerasan (Modifikasi Teori Persepsi Walgito 2014 dan Teori anak Wong 2009) 
Penelitian ini dilakukan di wilayah Kecamatan Telanai Pura Kota Jambi. Dimana populasi dalam penelitian ini adalah siswa - siswi usia sekolah di kota jambi. Dalam Penelitian ini sampel yang akan diambil adalah Siswa-siswi kelas 6 di SDN 47, SDN 69, SDN 208 Kota Jambi berjumlah 90 orang dengan perbandingan Akreditasi sekolah A,B dan C. Populasi merupakan seluruh karakteristik/sifat yang dimiliki oleh objek / subjek yang ditentukan oleh peneliti untuk dipelajari dan kemudian ditarik kesimpulan (Sugiyono, 2014). Teknik pengambilan sampel dengan menggunakan metode sampel jenuh. Metode sampel jenuh adalah teknik penentuan sampel bila semua anggota populasi digunakan menjadi sampel

Variabel - variabel yang di teliti dalam penelitian ini dapat dikelompokkan menjadi 2 yaitu variabel bebas dan variabel terikat. Variabel bebas persepsi kognisi, afeksi dan konasi sedangkan variabel terikat adalah kekerasan orang tua.

Analisis statistik deskriptif digunakan untuk menganalisis data dengan mendeskripsikan atau menggambarkan data yang telah terkumpul sebagaimana adanya tanpa bermaksud membuat kesimpulan yang berlaku untuk umum atau generalisasi (Sugiyono, 2014).

Analisis statistik inferensial dilakukan dengan cara analisis chi-square (bivariat) dan analisis regresi logistik berganda (multivariat). Analisis chi-square bertujuan untuk memeriksa hubungan antara variabel dependen dengan variabel independen secara parsial. Selanjutnya analisis regresi logistik berganda dilakukan untuk melihat hubungan antara variabel dependen dengan beberapa variabel independen secara simultan.

Sebelum melakukan pengumpulan data penelitian, terlebih dahulu akan dilakukan uji coba kuesioner untuk melihat validitas dan reliabilitas instrumen penelitian yaitu pertanyaan pertanyaan dalam kuesioner tersebut. Uji validitas instrumen dilakukan untuk menunjukan keabsahan dari instrumen yang akan dipakai pada penelitian sedangkan Uji reliabilitas digunakan untuk menguji keaslian hasil pengukuran kuesioner yang erat hubungannya dengan masalah kepercayaan

Tahap persiapan, Dalam pengumpulan data, peneliti melakukan tahap-tahap sebagai berikut: 1) Studi dokumentasi, studi pustaka, penyusunan proposal, dan dilanjutkan dengan ujian proposal; 2) Mengurus perizinan melakukan penelitian dari ketua program Magister, Universitas Jambi; 3) Kemudian mengajukan permohonan izin setelah itu peneliti mengambil data dari Dinas Pendidikan (SDN 47, SDN 69, SDN 208 Kota Jambi).

Tahap Pelaksanaan, Setelah mendapatkan responden, kemudian sampel dimintai persetujuan (informed consent) sebagai sampel penelitian dan menjelaskan tujuan penelitian kepada responden: 1) Pelaksanaan penelitian dilakukan pada bulan Juli 2020; 2) Memberikan kuesioner kepada sampel untuk diisi serta peneliti memberikan edukasi dan penilaian; 3) Data hasil penelitian dikumpulkan, kemudian dilakukan pengecekan; 4) Data yang telah dicek tersebut, kemudian diolah dengan program computer; 5) Pada tahap akhir dilakukan pembuatan laporan hasil penelitian; 6) Kuesioner yang diberikan responden menekankan masalah etika yang meliputi; 7) Lembar Persetujuan Penelitian (Informed consent) Sebelum kuesioner dibagikan kepada responden, terlebih dahulu peneliti menjelaskan maksud dan tujuan penelitian serta dampak responden selama pengumpulan data; 8) Anomity (Tanpa Nama) Untuk menjaga kerahasiaan identitas responden, responden tidak diharuskan untuk mencantumkan nama pada lembar kuesioner atau nama dicantunkan dalam inisial huruf.

Konsepsi Pengukuran, Kekerasan pada anak dapat berupa: 1) Kekerasan fisik; 2) Kekerasan psikis; 3) Kekerasan seksual.

Persepsi pada anak dapat berupa: 1) Kognisi; 2) Afeksi; 3) Konasi

\section{HASIL DAN PEMBAHASAN}

Analisis perhitungan berdasarkan hasil perolehan data selama masa penelitian berlangsung. Analisis akan dibagi menjadi dua, yaitu analisis deskriptif dan analisis hubungan untuk mengetahui hubungan antara persepsi orang tua terhadap perilaku kekerasan pada siswa dan siswi Sekolah Dasar Negeri di Kota Jambi. 
Uji validitas dilakukan dengan mengkorelasikan skor jawaban setiap butir pertanyaan dengan jumlah skor variabel. Teknik korelasi yang digunakan adalah teknik korelasi pearson product moment sesuai dengan skala ukur data ordinal. Angka yang dipergunakan sebagai pembanding untuk melihat valid atau tidaknya suatu item adalah 0,207 dimana sampelnya adalah 90 responden

Analisis deskriptif digunakan untuk memperoleh gambaran secara umum mengenai informasi umum responden, gambaran persepsi responden terhadap variabel persepsi orang tua dan perilaku kekerasan pada siswa dan sisi di Sekolah Dasar Negeri di Kota Jambi

Analisis Inferensial, atau Analisis hubungan digunakan untuk memperoleh informasi apakah terdapat keterkaitan antara faktor sosial ekonomi keluarga terhadap kekerasan pada siswa/siswi di kelas 6 Sekolah Dasar Negeri (SDN) 47, 69 dan 208 Kota Jambi. Analisis menggunakan korelasi chi square dengan jenis data kategorikal.

Pembahasan penelitian ini mendeskripsikan hasil penelitian untuk beberapa masalah penelitian yang telah dibahas pada bab sebelumnya yaitu (1) bagaimanakah persepsi siswa/siswi di kelas 6 Sekolah Dasar Negeri (SDN) 47,SDN 69 dan SDN 208 Kota Jambi terhadap perilaku kekerasan oleh orang tua, (2) Bagaimana perilaku kekerasan orang tua terhadap anak, (3) Apa hubungan antara persepsi orang tua terhadap prilaku kekerasan pada siswa/siswi di kelas 6 Sekolah Dasar Negeri (SDN) 47, 69 dan 208 Kota Jambi, adapun penjelasannya adalah sebagai berikut.

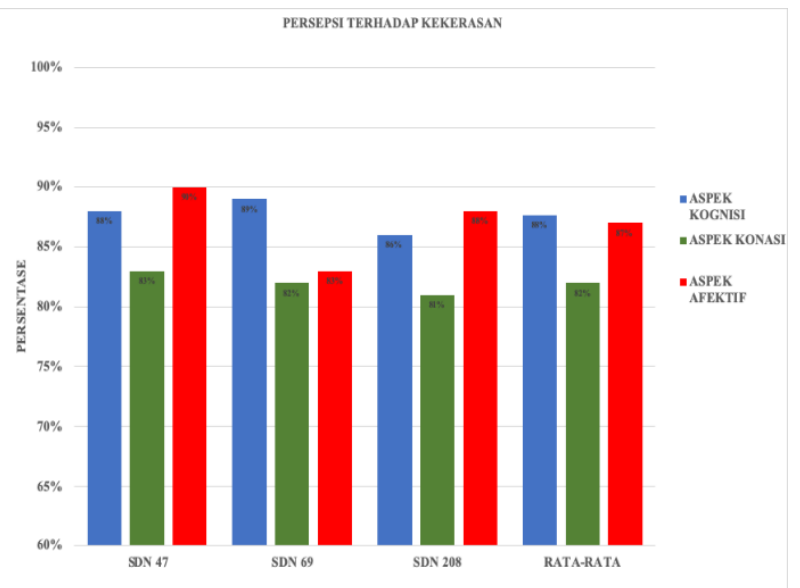

Gambar 4 Aspek Persepsi Anak terhadap Kekerasan

Berdasarkan data, persepsi siswa dan siswi kelas 6 terhadap kekerasan anak adalah siswasiswi tersebut memahami aspek kognisi, afeksi dan konasi (>80\%). Hal ini sesuai dengan Fisher, dkk (dalam Riyanti \& Prabowo, 1998) yang mengatakan bahwa komponen-komponen persepsi meliputi: aspek kognisi yang akan menjawab apa yang dipikirkan atau dipersepsikan tentang objek, aspek afeksi yang memberikan evaluasi emosional terhadap objek, dan aspek konasi yang berperan dalam menentukan kesediaan atau kesiapan jawaban berupa tindakan.

\section{SIMPULAN}

Persepsi siswa-siswi dari Sekolah Dasar Negeri 47, Sekolah Dasar Negeri 69 dan Sekolah Dasar Negeri 208 Kota Jambi terhadap perilaku kekerasan oleh orang tua berdasarkan aspek kognisi adalah positif yaitu sebanyak 88\% yang artinya siswa-siswi tersebut mengetahui dan memahami tentang perilaku kekerasan oleh orang tua. Persepsi siswa-siswi dari Sekolah Dasar Negeri 47, Sekolah Dasar Negeri 69 dan Sekolah Dasar Negeri 208 Kota Jambi terhadap perilaku kekerasan oleh orang tua berdasarkan aspek afeksi adalah positif yaitu sebanyak $87 \%$ yang artinya siswa-siswi tersebut merasa sedih apabila mengalami perilaku kekerasan oleh orang tua. Persepsi siswa-siswi dari Sekolah Dasar Negeri 47, Sekolah Dasar Negeri 69 dan Sekolah Dasar Negeri 208 Kota Jambi terhadap perilaku kekerasan oleh orang tua berdasarkan aspek konasi 
adalah positif yaitu sebanyak $82 \%$ yang artinya siswa-siswi tersebut tidak setuju terhadap kegiatan/perbuatan kekerasan baik secara fisik, psikis maupun seksual oleh orang tua.

Jenis kekerasan yang paling banyak dialami oleh siswa-siswi Sekolah Dasar Negeri 47, Sekolah Dasar Negeri 69 dan Sekolah Dasar Negeri 208 Kota Jambi adalah kekerasan psikis yaitu 81 kasus ditemukan pada responden (23\%). Jenis perilaku kekerasan Psikis yang dialami oleh siswa-siswi Sekolah Dasar Negeri 47, Sekolah Dasar Negeri 69 dan Sekolah Dasar Negeri 208 Kota Jambi adalah diejek dengan 48 kasus (13\%)

Faktor sosial ekonomi yang memiliki korelasi signifikan terhadap perilaku kekerasan adalah pendidikan ibu ( $\mathrm{p}$-value $=0.02)$ dan usia ibu $(\mathrm{p}$-value $=0,04)$ dimana nilai probabilitas menunjukkan nilai yang kurang dari 0,05. Dengan demikian artinya bahwa pendidikan ibu dan usia ibu memiliki keterkaitan dengan perilaku kekerasan pada anak..

\section{DAFTAR PUSTAKA}

Banton, R. (2004). Childhood Study . Australia: Blackwell Publishing.

Firdinan, M. F. (2008). Membina Keluarga Harmonis. Yogyakarta: Tugu Publisher.

Gelles, R. J. (2004). Child Abuse. New York: Encyclopedia Article from Encarta.

Huraerah, A. (2007). Kekerasan Terhadap Anak. Jakarta: Penerbit Nuansa.

KPAI. (2018). Laporan Kinerja KPAI-2017. Jakarta: KPA Indonesia.

Pratiwi, N., \& Khusnul, E. (2014). Perbandingan Persepsi Tentang Kekerasan Anak Berdasarkan

Karakteristik Demografi Orang Tua di Dusun Mantaran Trimulyo Sleman Yogyakarta

Stikes Aisiyah. Jurnal Pendidikan.

Riyanti, D., \& Prabowo, H. (1998). Psikologi Umum. Jakarta: Universitas Gunadarma Press.

Sobur, A. (2003). Psikologi Umum. Bandung: Pustaka Setia.

Sugiyono. (2004). Metode Penelitian. Bandung: Alfabeta.

Suteja, J., \& Ulum, B. (2019). Dampak Kekerasan Orang Tua Terhadap Kondisi Psikologis Anak

Dalam Keluarga. Qualita, 1(2), 169 - 185.

Tampubolon, M. (2008). Perilaku Keorganisasian. Bogor: Ghalia Indonesia.

Vaughan, R. P. (1996). Child Abuse and Its Consequences. Human Development Magazine, 17(2).

Walgito, B. (2014). Pengantar Psikologi Pendidikan . Jakarta: Andi.

Wibowo. (2014). Perilakuk Dalam Organisasi. Jakarta: Rajawali Pers.

Wong. (2009). Buku Ajar Keperawatan Pediatrik. (Alih Bahasa: Andry Hartono, dkk). Jakarta: EGC. 